\title{
Staging the Buddha: Victor Segalen's Siddhârtha and the Unsettlement of Western Culture
}

\author{
SAMUEL THÉVOZ \\ Université Sorbonne nouvelle (Paris 3) \\ samuelthevoz@gmail.com
}

Keywords: Victor Segalen, Literary Globalization, Theatre History, Orientalism, Life of the Buddha, Modern Buddhism, Literary Geography

DOI: https://dx.doi.org/10.15239/hijbs.01.01.07

Abstract: Colombo, November 1904. Returning from Tahiti to France after an almost two-year trip, a dispatch boat made an unforeseen six-week stop-over. Victor Segalen (1878-1919), the French famous post-Symbolist poet, had been appointed as the shipboard physician. During this unplanned stay, Segalen encountered Theravādin Buddhism and was inspired to write a play not on the Buddha as god, idol, or myth, but on the human life of Siddhārtha Gautama, the historical Buddha. Segalen did not fully know at the time that similar dramatic projects had already been attempted by other European writers and artists. Furthermore, he soon discovered that his own encounter with Buddhism took place at a crucial point of world history. By writing a play on the Buddha, Segalen actually testified to an era of unsettlement in which Buddhism, Empire and Modernism met. I argue here that a contextualized analysis of Segalen's drama helps delineate important and underestimated transnational and cross-cultural issues of the early twentieth century. 
Colombo (in Ceylon, today's Sri Lanka, then a British crown colony), November 7, 1904. Returning from Tahiti-a French Establishment in Oceania-to France after an almost two-year trip, a dispatch boat named La Durance was to make an unforeseen sixweek stop-over. Victor Segalen (1878-1919), the famous French post-Symbolist poet, had been appointed as the ship's physician. This unplanned stay led to his immersion in Theravādin Buddhist culture. The European view at the time held Theravāda as a mirror of Buddhism's pristine origins. In Tahiti, Segalen discovered painter Paul Gauguin's (1848-1903) last works and paid attention to the recurrent idol-like figure of the Buddha among the Gauguin's primitivist artefacts. ${ }^{1}$ Through his encounter with Buddhist practitioners in Ceylon, Segalen came to the idea that the Buddha was neither a god, an idol or a myth. Almost immediately, the poet felt the urge to write a drama on the human life of Siddhārtha Gautama, the historical Buddha. The piece he envisioned was simply called Siddhârtha, and he worked on this piece until the very last years of his life. This early travel experience nourished a comprehensive reflection on exoticism and otherness that Segalen would develop throughout his literary work.

Segalen did not fully know at the time that other European writers and artists had attempted similar dramatic projects. Furthermore, he soon discovered that his own encounter with Buddhism took place at a crucial point of history. By writing a play on the Buddha, Segalen actually testified to an 'age of entanglement', ${ }^{2}$ in which Buddhism, Empire and Modernism met. While Buddhism was still a relatively new field of scholarly Orientalism, it quickly made its way into fin de siècle arts and literature, and was becoming more and more appealing to many Westerners as a spiritual alternative to Christianity. Buddhism was also perceived both in the East and

\footnotetext{
1 Cata, Le Siddhârtha, 35-54; Zafran, Gauguin's Nirvana, 103-28.

2 Manjapra, Age.
} 
in the West as an effective solution for the struggles of colonialism, industrialization and internationalization at stake in the process of global modernization. ${ }^{3}$ Although Siddhârtha remained an unpublished work during his lifetime, Segalen's endeavour stands as an underestimated contribution to the cultural de-centering that the encounter of Europeans with Buddhism triggered. Not only is Siddhârtha highly concerned with opening up French drama to the non-Western world, it also highlights how Buddhism took part in the rise of modern arts. Relying on up-to-date scholarly sources, Segalen challenged the previous French adaptations of the life of the Buddha. From the perspective of theatre history, his project of staging the life of the Buddha also caused him to step away from the literary and theatrical trends of his time, like Naturalism and Symbolism; he thus defines his own approach to 'exoticism'. First and foremost, these aesthetic issues actually underscore the reasons why the author, who is known as a poet rather than a playwright, chose theatre in particular as an unrivalled means to reflect upon the global world's awakening at the turn of the century.

Segalen's understanding of Buddhism provided him with a renewed perception of the world that stands apart from Western cultural patterns. I think, therefore, that Siddhârtha deserves to be considered as more than a mere retelling of the life of the Buddha on stage. The play calls for a thorough investigation of its dramatic features. Among these, dramatic space-including Segalen's instructions regarding the setting, his directions for the stage and the relationship between the characters and their dramatic environment - bears the significant mark of Segalen reshaping his vision of the world. At a time we can fruitfully refer to as an era of unsettlement, ${ }^{4}$ space (rather than characters or time, for example) becomes in Segalen's eyes a key notion for his own aesthetic of Diversity. ${ }^{5}$ In his first notes for the project of his famous Essai sur l'exotisme. Une esthétique du Divers, Segalen states that 'exoticism' means 'everything

\footnotetext{
3 Bocking et al., A Buddhist Crossroads.

4 Geyer and Bright, 'World History', 1053.

5 All translations are mine throughout.
} 
that is "outside" the realm of our current and daily consciousness, everything that is not our ordinary "mental tonality". Thus, Exoticism in Time / in Space.' He adds: 'In Space: the only one that I shall develop' ${ }^{6}$

From a literary perspective, space is, on the one hand, a theatrical and dramatic feature, because it is both intrinsically specific to the performing arts, and because nineteenth-century theatre was especially eager to stage geographic places and to realistically depict both familiar and exotic cultural worlds. On the other hand, as recent spatial studies tend to argue, it greatly helps in understanding the context of globalization. Indeed, in this critical moment of colonization and imperialism at the turn of the century, geographic space became a sensitive issue both literally and symbolically. Since the notion of space allows us to think of theatre and the global world together, it is naturally the connecting thread of the following investigation.

\section{Theatre going global in the late nineteenth century}

Most studies that examine French theatre in its connections with Asia consider Antonin Artaud's Le Théatre et son double as a historical landmark (most notably Bharucha, Theatre and the World). Artaud's collection of reflections on theatre from 1930s, which includes 'Sur le théâtre balinais' and 'Théâtre occidental et théâtre oriental', certainly played a leading role in the development of dramaturgy in the twentieth century, ${ }^{7}$ notably in the works of Peter Brook and Ariane Mnouchkine, who advocated for Artaud in the 1980s and claimed that 'theatre is oriental'. ${ }^{8}$ More recently, studies have emphasized the seminal importance of World Exhibitions, among them the Parisian 1889 and 1900 Expositions universelles and the subsequent 1931 Exposition coloniale, in the renewal of theatrical conceptions ${ }^{9}$

\footnotetext{
6 Segalen, Oeuvres I, 748.

7 Pavis, The Intercultural Performance.

8 Mnouchkine, 'Theatre is Oriental', 97.

9 Savarese, Eurasian Theatre.
} 
and arts in general. For instance, Debussy's debt toward Indonesian performances in such exhibitions, as well as Artaud's understanding of Balinese theater later on in the thirties, are well known to scholars of theater history.

In the aftermath of postcolonial studies, this new focus on the history of global exchanges in the late nineteenth century underlines the development of exoticism as an imperial manifestation of Western metropolitan supremacy on its peripheries. Indeed, a number of popular theatrical and lyrical shows staged colonial encounters involving 'Oriental' (usually Middle Eastern) scenery. ${ }^{10}$ In this context, the success of Japanese stage icon Sada Yacco in the 1900 Exposition universelle and her influence on modern dancers such as Loïe Fuller and Isadora Duncan have been recently studied. ${ }^{11}$

\section{The 'Buddhist culture' in France and the life of the Buddha in the arts}

During this early phase of globalization, these diverse manifestations of material and intellectual contact and (mainly asymmetrical) interactions between European stages and Asian cultures and theatrical traditions, both in popular and avant-garde public spheres, offer nuanced examples of what Edward Said defined as Orientalism. In the course of nineteenth century, developments in philology show the most prominent cases of Orientalism in academia. Stepping away from the Mediterranean Basin, scholars turned to the study of Eastern and Far-Eastern texts and cultures. Eugène Burnouf's Introduction à l'bistoire du buddhisme indien is the most prominent work to be mentioned here, since it can be seen as the corner stone of Buddhist studies, though some scholars argue that there have been earlier glimpses of Buddhism. ${ }^{12}$ This work significantly impacted European cultural history during the second half of the

\footnotetext{
10 Ziter, The Orient.

11 Fujii and Triau, Scènes françaises.

12 App, The Birth.
} 
century. ${ }^{13}$ We must also consider the development of Buddhist studies throughout Europe during this period, and the major influence of, and on, Schopenhauer in this regard. ${ }^{14}$ If we focus on France, we see that Buddhist studies played a leading role within Indian and Eastern studies. ${ }^{15}$ Their influence is particularly visible in French fin de siècle artistic milieus, resulting in historians drawing the outlines of a French 'Buddhist culture'. ${ }^{16}$ Late nineteenth and early twentieth century poets and novelists such as Jules Laforgue (Les Complaintes), Jean Lahor (La Gloire du Néant) and André Beaunier (Le Roi Tobol) exemplify this impact of Buddhist studies on art. In their works, this influence is combined with the Schopenhauerian metaphysical pessimism that developed in Decadent and Symbolist circles at the time.

Plays from the 1890s such as Albert Samain's Tentation $d u$ Bouddha or Maurice Bouchor's Naissance de Bouddha (Mystères) also contribute to the French 'Buddhist culture' with their projects of staging the life of the Buddha. ${ }^{17}$ These authors grounded their works on the information on the life of the Buddha and on Buddhism found in Burnouf's study and Philippe Édouard Foucaux's 1847 translation of the Lalitavistara Sutra. Segalen only became acquainted with these early tentative adaptations when he returned to France from Ceylon. He could then draw material from more recent scholarly inquiries available, including German Indologist Hermann Oldenberg's Buddha. Segalen also relied on Samuel Beal's The Romantic Legend of Śäkya Buddha and British Pāli scholar Thomas Rhys David's Buddhism.

In their literary reworking of the available scholarly material, ${ }^{18}$ the

\footnotetext{
13 Almond, The British Discovery; Droit, Le Culte.

14 App, Schopenhauers Kompass.

15 Lévi, 'Les parts respectives'.

16 Of course, the phenomenon was not limited to France and developed worldwide. For a study of British Buddhist literary history and the ties between modern aesthetic and Buddhism, see Franklin, The Lotus and the Lion.

17 Cata, Le Siddhârtha, 16-23.

18 Détrie, 'Le Bouddha'.
} 
authors tended to use the East as exotic decor ${ }^{19}$ or as a metaphysical realm..$^{20}$ They were interested in the life of the Buddha insofar as it provided them with a new topic and figure: the Buddha represented an Eastern alternative to the figure of Christ. ${ }^{21}$ These authors also felt that this unexplored material could give a modernist twist to the medieval theatrical tradition of mystery plays, which Symbolist playwrights revived at the end of the nineteenth-century. ${ }^{22}$ Bouchor explicitly integrated the life of the Buddha into a syncretic perspective on the spiritual history of humanity, whereas Beaunier decontextualized the story of the Buddha and set his novel 'out of the world,' in accordance with the Symbolist aesthetics.

These different aspects of the 'Buddhist culture' in the arts at the end of the century-not to mention German, British and American dramas on the same subject-clearly point to an underestimated phase of unsettlement of European cultural patterns.

\section{Re-reading Siddhârtha or the drama of the unsettlement of space}

Like his predecessors, Victor Segalen envisioned an encounter with the East as a resource for regenerating Western thought and aesthetics. His drama Siddhârtha is best understood in the context of the Buddhist-oriented vision of the East that constituted a basic assumption in his cultural background. ${ }^{23}$ I want to focus on this play because, in staging the life of the Buddha, Segalen departs from the projects of his predecessors, projects that he was well acquainted

\footnotetext{
19 Samain, La Tentation.

20 Bouchor, Mystères, 1-32.

21 The life of Jesus Christ was actually a conflictual issue since the positivist approach of Ernest Renan's polemical Vie de Jésus (see Kaempfer, Points de vue, 111-44).

22 Folco, 'Dramaturgie de Mallarmé', 230-47; Lucet, 'Le “Théâtre en liberté” des symbolistes', 193-339; Thévoz, “Mystères” bouddhiques'.

${ }^{23}$ App, The Cult.
} 
with. ${ }^{24}$ In contrast to them, Segalen, following Oldenberg's perspective, insists on the human condition of the Buddha-to-be rather than on the mythical or legendary ornaments of the Buddhist tradition. ${ }^{25}$ This certainly explains why the play is called 'Siddhartha' (the Buddha's given name) and not 'The Buddha' (a title reflecting the enlightened state he attained). While critics already have delineated central aspects of the play, ${ }^{26} \mathrm{I}$ want to argue that the play is not limited to the 'story' of one human being-even a highly venerable one-and does not follow the conventions of a single dramatic school. Segalen indeed kept amending the play and formulating other possible versions. In a note on the play dated from 1911, he interestingly comments on the dramatic dimensions and goes beyond the mere transposition of the biography of the Buddha:

I was immediately urged to write this man's story; I wanted first to recreate scrupulously its genuine atmosphere; but I right away changed my mind and thought of giving it a new literary form; drama, or at least dramatic dialogue, was the obvious form to adopt. I would then have to write in a noble way and with a maximum degree of evocative power the scenery, the movement, the interaction of the surrounding world with the emotions and inner bursts of the hero. ${ }^{27}$

Critics have usually read this statement of intention as the author's decision to stick to the story of a man rather than to legendary tales. However, this reading leads too quickly to a bowdlerized version of the dramatic dimension the author intends to give to his work. Indeed everything, from the dialogues to the stage directions, is thought out in dramatic terms. Moreover, this note gives clues to the

24 The manuscripts available at the French National Library (BNF) explicitly refer to his readings at the time of composing the play.

25 Segalen, Siddhârtha, 117.

26 Cata, Le Siddhârtha; Cordonier, Victor Segalen, 65-183; Détrie, 'Siddhartha'.

27 Segalen, Siddhârtha, 117. 
way Segalen intends to give a Buddhist twist to his conception of dramatic space. Even though Segalen did not obtain much recognition in the field of theatre, he most certainly sensed that this genre was an outstanding modern (inter-)cultural force, provided that drama was stripped of its dramatic conventions and transformed into a 'new literary form'.

One can argue, however, that 'space' is the key concept to grasp the originality of Segalen's work. ${ }^{28}$ This dimension is best underscored if we view his concept of the dramatic space from the perspective of the 'first phase of globalization', as historians have recently called the period. As we have seen, Geyer and Bright use the notion of 'unsettlement' to describe the fundamental shifts arising at the end of the nineteenth century. This notion fits well to account for the processes of cultural transformation implied by the 'age of globality' ${ }^{29}$

This historical phenomenon is mirrored in Siddhârtha's trajectory in the play and the character's progressive loss of points of reference. We can read the effects of unsettlement both on a concrete level-dramatic and scenographic (the 'material' aspects of the settings and of the movements of the characters on stage) - and on a symbolic and philosophical level (a character disoriented in a radically de-centered world). The choice of drama, rather than any other literary genre, thus finds legitimation. Moreover, Segalen's famous definition of exoticism as an 'aesthetic of the diverse'30 therefore pertains equally to drama. The play simultaneously sheds light on the unstable relationship of the imperial West with its Eastern peripheries.

I would then argue that the Buddhist-oriented vision of the world inscribed in such a play goes along with the important shift implied by the 'unsettling' processes of globalization. These processes provided an author like Segalen with unexpected intercultural insights and led him to radically reconsider his concept of space. From an autobi-

\footnotetext{
28 Winspur, La Poésie du lieu; Knebusch, Poésie planétaire.

29 Balme, 'Conceptualizing'.

30 Segalen, Oeuvres I, 745-82.
} 
ographical perspective, Siddhârtha (the character) parallels the quest for the aesthetics of Diversity that the author develops throughout his work. Moreover, Siddhârtha (the play), sketched as a quest for a culturally new horizon, is a product not only of the French 'Buddhist culture' of the time-contrary to Samain's or Bouchor's projects-but also the outcome of an intercultural encounter. Siddhârtha meaningfully embodies such historical processes through the encounter with non-European cultures.

These remarks alone require preliminary methodological clarification. They sustain the idea that the notion of 'unsettlement' as described above seems much more accurate and fruitful in Segalen's exoticist dramatization of the discovery of the unknown, than the commonplace idea of the Freudian 'uncanny', ${ }^{31}$ for example. Freud drew on the Romantic writer E. T. A. Hoffmann's fantasy short story 'Der Sandmann' to describe the hidden effects of social taboo on one's subconscious. The concept was designed to describe hidden processes of the psyche and literary critics have also readily applied it to Symbolist literature, and to Maurice Maeterlinck's first dramas in particular. According to such a view, the unknown was envisioned as a threat coming from the outside. Likewise, the later argument of Freud's Civilization and its Discontents (Das Unbehagen in der Kultur) is limited to the tensions between culture (on the side of the unconscious and super-ego: society, religion) and the individual (on the side of the ego and the instinct for freedom).

As one can see, this set of interpretations misses a dimension that is crucial to Segalen at his time, a dimension that we might call, merely paraphrasing his own critics of exoticism, the crisis of space. While the notion of 'unsettlement' somehow reformulates the very ideas contained in the words 'Unheimlich' and 'Unbehagen' (implying a disquieting process), it steps away from the psycho-analytical paradigm and focuses more specifically on historical spatial concerns.

31 Freud, The Uncanny. 


\section{An exotic setting and a static character: a distance away from set patterns}

We can clearly see the scope of manifestations of unsettlement through the trajectory followed by Siddhârtha, the eponymous and main character of this 'drama in five acts'. In the inventive Prologue that precedes the drama, strictly speaking, the newborn Siddhârtha's flowered cradle, placed in the middle of the stage, is the object submitted to the dramatis personae and the virtual audience's gaze and speech. The drama takes place in the Śăkya Palace surrounded by exotic scenery set in Ancient India, at the feet of the Himalayas, in the surroundings of Lumbini (in nowadays Nepal), accordingly to the Buddhist narratives. ${ }^{32}$

Contrasting with the disposition of the Prologue, Act I is set outside the city, at the feet of the battlements. The action shows Siddhârtha violently breaking out the chains that keep the heavy doors of the city locked. The overture of the play is then a clear moving away from Siddhârtha's familiar world (which is for the audience a familiar exotic world). The protagonist makes this clear when he complains that he is being haunted by his 'anguishes' which he calls his 'familiar companions'.

On an aesthetic level, this moving away from the social and religious order is also designed in the play as a departure from both Naturalist and Symbolist dramaturgy and implies the quest for a new conception of the world. ${ }^{33}$ As such, we can read the Prologue as a critique of the Naturalistic bourgeois indoors settings and family-focused dramas popular on Parisian stages at the time. It can be read also as a pastiche-rather than a mere copy ${ }^{34}$ - of avant-garde Symbolist plays, transposed here into an exotic setting. This is

32 I do not intend here to evaluate from a philological perspective Segalen's faithfulness to and consistency toward Buddhist sources. I rather want to highlight how his encounter with and understanding of Asia and Buddhism modified his vision of the world.

33 Losco-Lena, La Scène symboliste, 13-44.

34 Cordonier, Victor Segalen, 83. 
reminiscent of Maurice Maeterlinck's L'Intruse and Intérieur, in which anguish and terror take hold of the characters from the start. Pelléas et Mélisande, which made a strong impression on Segalen, comes even more clearly to mind. The drama is staged in the king of Allemonde's isolated castle, where the interior spaces are mysteriously bound to the castle's surroundings - be they staged (a park, a forest, a grotto) or left off-stage as invisible and unlocated far-away dreamworlds (Mélisande's birthplace, the sea, the bottom of the fountain) - through symbolic thresholds (a gate, a hall, a window, a terrace).

Segalen's play re-orders this aesthetic inheritance in its own fashion. In the perspective of the general motion that directs the plot, Act II, closing the 'First Night,' is Siddhârtha's distressed adieu to the conventional world, while Act III, centered like all other acts on the main character, opens the 'Second Night' of the play and sets the scene for the rest of the drama in the savage world of the forest. This wilderness, where Siddhârtha devotes himself to ascetic austerities, is depicted as an ereme, a desert outside social and cultural boundaries, and contrasts completely with the aekumene, the anthropic world..$^{35}$ This dichotomy eventually appears in the play as a pure fantasy, however. Not having obtained 'deliverance' through yogic practices, meditation or the acquisition of supernatural powers (Act IV), Siddhârtha obtains 'Illumination' (Enlightenment) through a visualization of the 'pictures' ('Visions') of all sceneries set on stage until then (Act V'Epilogue').

One can sense clearly that the focus on space is the critical dimension at the core of the drama. It is, for example, significant that the character should speak of his own trajectory using the word 'chemins' (paths) to be found/invented rather than 'Routes' to be followed. The term 'Routes' might refer here to the yana ('vehicles'): the different Buddhist traditions known as Hīnayāna (the 'small vehicle') and Mahāyāna (the 'great vehicle'), corresponding to the distinction between Southern Buddhism and Northern Buddhism used by scholars at the time of Segalen. In Siddhârtha however, the term 'Route'

35 Berque, Écoumène, 141-294. 
actually turns out to be deceptive and inadequate. From the start, space is thus not a given; it is inscribed in a process. In contrast, other characters (Channa his servant and 'driver', Krisha his cousin, or the crowd) insist on the conventional term 'Voie' (Way) to describe Siddhârtha's spiritual progression. Segalen thus emphasizes the Buddhist spatial metaphor of the Fourth Noble Truth (magga sacca, the Truth of the Path in Pāli) which exists in the Eightfold Path leading to nirvāna, notably via the realization of impermanence and the cessation of attachment.

V. Siddhârtha and the aesthetics of Diversity in the wake of the global world

The dramatic use of space in Siddhârtha signals, as I have suggested, a distancing from Naturalist conventions and, simultaneously, from the Symbolists' withdrawal from the world and their refuge in the cult of Art. Although this move is less clear in Segalen's literary project and in his attitude towards art, Segalen's play stages an open world where the East symbolically stands at the horizon of the West, implying a redefinition of the key-term 'exoticism' as the settings in Siddhârtha suggests. As such, Siddhârtha is an early enactment of the 'aesthetics of Diversity', a formula which is the subtitle of Segalen's Essai sur l'exotisme. The essay is a compilation of notations dating back to the years 1904 to 1918 . It presents the theoretical issues of Segalen's literary projects and aesthetics as underlining their focus on 'everything that is Other' ['tout ce qui est Autre']. ${ }^{36}$ The propositions collected in the Essai have been the focus of numerous studies in literary criticism, cultural anthropology and history (notoriously Clifford, The Predicament; Todorov, Nous et les autres; Baudrillard, La Transparence du Mal; Glissant, Introduction). More recently, Charles Forsdick has highlighted the fact that Segalen's 'exoticism-or Aesthetics of Diversity-focuses on the instability of contact between different cultures and represents a

\footnotetext{
36 Segalen, Oeuvres I, 778.
} 
unique response to the decline of diversity triggered by colonialism and Westernization', ${ }^{37}$

\section{Segalen's encounter with Buddhism: a crisis of values}

In order to renew, nuance and contextualize the author's sometimes ambiguous or even contradictory conception of Diversity and otherness, Forsdick puts the Essai into perspective and draws mainly on Segalen's travels (his 'physical circumnavigations') to Polynesia and China. ${ }^{38}$ In this respect, as I have noted previously, Siddhârtha must be regarded as the product of his encounter with Buddhism during a forced halt in Ceylon on his way from Polynesia (1903-1904). Segalen was returning home to Brittany as a physician, before leaving again for a later stay in China (1908-1914), where he was active both as a physician and as an archaeologist. He relates his stay in Colombo and Kandy (November 7-December 22, 1904) in his Journal des illes ${ }^{39}$ where he mentions simultaneously his visits to the Buddhist college of Vidyodaya, his admiration for Buddhist statuary, his encounter with Selananda, a young Theravada monk (his 'initiator'), his wariness of devotional practices, his attraction towards canonical texts and the 'pure, crystalline, admissible' teachings of the Buddha, notably the latter's rejection of the notions of soul and personality, as well as the overall consistency and moral perfection of what he calls the 'Buddhist psychology'.

He does admit, however, that he would not become a Buddhist because, contrary to most of his fin de siècle predecessors, he cannot accept the first Noble Truth (suffering) as the basis of his own philosophy. This encounter leads him to acknowledge the religious tolerance that he considers a genuine 'Hindu, Vedic and Buddhist' virtue. Moreover, whereas he explicitly casts suspicion on Theosophists, such as Colonel Olcott and Madame Helena Blavatsky, who tried to

\footnotetext{
37 Forsdick, Victor Segalen, back cover.

38 Forsdick, 102-81.

39 Segalen, Oeuvres I, 456-66.
} 
revitalize Buddhism in India and Sri Lanka at the time, he begins to learn Pāli in order to access canonical texts of Buddhism directly.

One might object that Segalen's encounter with Buddhism testifies to what Edward Said calls a 'textual attitude' toward the Oriental, privileging the study of original texts to the actual interaction with the Other and the recognition of the legitimacy of the Other's cultural practices..$^{40}$ In order to understand by contextualizing, rather than to comprehend ex post facto the global forces at stake here, I would only like to point out that we can read Segalen's narrative of his encounter as the sign of a crisis of values inside the colonial 'process of contact between cultures'. ${ }^{41}$ Here, we can read travel as a 'physical circumnavigation ${ }^{342}$ in the same terms as the trajectory of Siddhârtha in Segalen's play, which he wrote as a consequence of his sojourn in Ceylon. Additionally, Segalen's direct encounter with Buddhism is also the sign of a significant shift inside French 'Buddhist culture', since Siddhârtha offers something other than an apology of the Buddha as a rejection of Judeo-Christian tradition or as a spiritual rejection of the material world in European fin de siècle. In order to understand this internal shift, we need to make a brief point about Segalen's encounter with Buddhism in 1904 before we analyze the implications of the discovery of Buddhism in the treatment of dramatic space in Siddhârtha.

Segalen's attitude toward Buddhism is significantly ambivalent in his Journal des illes. On the one hand, he admires the Buddhist core principles. On the other hand, he formulates a less favorable opinion after his discovery of Buddhism in Ceylon: 'it is really a pity that there is only one word 'Buddhism' to point at so many various realities ('diversités') and that this word itself is comical, stocky, pot-bellied, paunchy, and blissfully dumb'. ${ }^{43}$ This apparent contradiction calls for some explanation.

First, the traveler envisions the possibility of an existential com-

\footnotetext{
40 Said, Orientalism, 92-96.

41 Forsdick, Victor Segalen, 98.

42 Forsdick, 60.

43 Segalen, Oeuvres I, 459.
} 
mitment to Buddhism, at a time when Westerners like Alexandra David-Neel, for example, stepped away from the philosophical idea of Buddhism inspired by Schopenhauer and turned instead to concrete forms of Buddhism, ${ }^{44}$ becoming converts themselves and contributing to the rise of Buddhist modernism on a global scale. ${ }^{45}$ Second, and it is my main point here, although Segalen does not make a personal commitment to the Buddhist path, he acknowledges and discriminates different forms and practices inside what Western scholars have designated as a global Asian phenomenon. Segalen's acquaintance with Buddhism in Ceylon leads him to adopt a new vision that differs from simplified European exotic representations, such as the images of the Chinese-like curios inherited from eighteenth century chinoiseries he mentions here. If, like most 'modern Buddhists' at the time, he believes to have found in 'Southern Buddhism' a purer form of the message of the Buddha than would have been available in what was used to be called 'Northern Buddhism', his conclusion made after his stay at Colombo is to be taken in earnest: his travel away from European libraries has led him to the recognition in situ of Diversity beyond false appearances constructed by European scholars and writers through Eurocentric categories.

\section{On the edge of two cultural worlds: from the biography to the play}

While European colonial culture confronted the notion of the 'end of travels and explorations' ${ }^{46}$ and began to deplore the 'levelling of all cultural differences', ${ }^{47}$ Segalen sought a way out of what took the shape of a crisis in the representation of space. To me, this appears to be the reason why he chose to stage an apparently motionless char-

\footnotetext{
44 Thévoz, 'On the Threshold'.

45 Lopez, A Modern Buddhist Bible; MacMahan, The Making.

46 Reichler, 'Frontières du monde'.

47 Forsdick, Victor Segalen, 5.
} 
acter in the mood of the 'static drama' of Symbolist dramaturgy. ${ }^{48}$ He does this by focusing the drama on the notion of suffering, the First Noble Truth of Buddhism. In Buddhist philosophy, suffering is the consequence of ignorance, and needs first to be realized as such. Significantly, Segalen gives this specifically Buddhist conception a spatial treatment through Siddhârtha's breakthrough in Act I and his stepping into the unknown: 'Nobody ever taught me... Whatever, on my way I shall discover.... ${ }^{49}$ He then has to step beyond what he 'sees, guesses, knows, feels' ${ }^{50}$ He thus acknowledges unsuspected geographical and cultural/social realities from the beginning: ${ }^{51}$ 'There are men and things outside my city! But, the world does not end at these walls...'). The character's trajectory is indicated in the play by ever-changing surroundings. In Act V, where every aspect of reality sublimely dissolves, Segalen's stage directions produce an atmosphere resembling the 'féerie' - a genre which was very popular in French theatres at the time. ${ }^{52}$

On the whole, the idea of an individual and personal process (a subjective experience) certainly goes along with the tradition of the mystical quest such as it is found in the Christian tradition which inspired Bunyan's The Pilgrim's Progress. My point is nevertheless that Segalen makes sense of the Buddhist search for Enlightenment by virtually staging Siddhârtha's quest with the features of the principles of transience, impermanence and formlessness. Whereas Act I shows a distancing from social conventions, Act II stages Siddhârtha's interior state of mind to be in correspondence with the cosmic world: ${ }^{53}$ 'The sky is boiling as is my head'; the coming monsoon progressively modifies the setting, reflecting Siddhârtha's inner conflicts and psychological disintegration. If this interdependence between macrocosm and microcosm is a convenient trick to give the audience a vision of

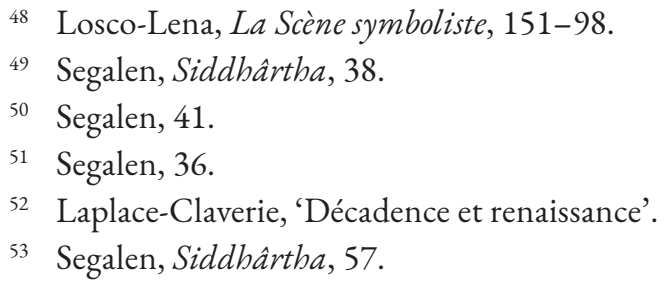


the character's inner self, it can also be connected with the Symbolist rejection of the social world and also simultaneously with Indian cosmology. What is at stake here though, is Siddhârtha's distancing from the interpretations of the world uttered by his own father (Souddhodana) and a prophet (the Ascetic) in the Prologue. Stepping away from these two figures' mythological pronouncements, Siddhârtha comes to realize in Act II that his own mind needs to be stripped from such visions and reach the true nature of things-emptiness (śunyatā): 'Ha! If I could once see the firmament empty!'. ${ }^{44}$ As one can see, this central doctrinal aspect of Buddhism directly affects the conception of dramatic space and radically unsettles the character's and the reader/audience's vision of the world.

\section{From exotic setting to symbolic geography: a cross-cultural dramatic space}

The relationship to space in the drama not only draws on this macro-microcosm pattern but also elaborates, as I would like to argue, on a symbolic geography which gives a more fundamental exotic dimension to the play. Had the play been staged, it would have certainly been perceived as a totally different representation from the Christian/scientific point of view of the audience at the time and would have escaped the codes of colonial exoticism. This, by the way, could be an unexpressed reason why 'Claude de France' (Debussy), the famous composer of the score of Pelléas et Mélisande in 1901, eventually rejected the project to write the music for Siddhârtha. Although Debussy himself was inspired by Asian arts, he somehow felt thrown off by this 'prodigious dream', 55 in which the text was too 'musical' in itself to be supplemented by any music score. ${ }^{56}$ The composer suggested instead to the poet that they work together on

\footnotetext{
54 Segalen, 57.

55 Joly-Segalen, Segalen et Debussy, 217.

56 This actually was a common issue in the Symbolist aesthetics. See Losco-Lena, La Scène symboliste, 113-50.
} 
the myth of Orpheus, which he certainly perceived as a more manageable - and culturally familiar-topic.

Like the indications of settings inspired by Segalen's readings of Beal and Oldenberg, the dramatic space is based on a schematic square-like representation of the universe described in Act I. The four-wall fortified city and, ${ }^{57}$ inside it, the 'Santhagara', ${ }^{58}$ the official Assembly Hall, offer the reader/audience with the symbolical miniaturization of the universe materialized on stage. This structure is consistent with the characters' discourse and hence with their vision of the world. For instance, in the Prologue, the Ascetic prophesizes that Siddhârtha will become the 'Lord of the world and the King of the four Kingdoms'. ${ }^{59}$ Thereafter, Siddhârtha's quest is transcribed as a disorientation formulated as a loss of the 'four directions,' which goes along with the fact that, as I noted before, the search for the 'Way' is reduced to a cautious exploration of 'paths'.

In the stage directions of Act III, the dramatic space is then described as divided in four spaces around the central figure of Siddhârtha. ${ }^{60}$ The square-structure of the mandala is a visualization of a yogi's mind during Buddhist meditation. In this widely spread conception of the Mahāyāna tradition, the world becomes an emanation of the mind. Although Segalen claimed to draw on the Southern Buddhist tradition concerning the biographical narratives of the Buddha, his manuscript notes testify to the fact that he used 'Northern' sources to develop the dramatic aspects of the drama. Among them, the idea that the dramatic space is to be considered Siddhârtha's 'vision' is central to the project. For instance, in September 1906 he writes that the settings have to take part in the plot and that the stage merely reflects Siddhârtha's 'motions' (inner sensations and thoughts). Ultimately, the stage becomes thus, Segalen notes, a 'vanishing mirage'. In 1907 he adds a comment in the margin of the text: 'I say it to you, in this only six-feet-tall

57 Segalen, Siddhârtha, 36.

58 Segalen, 55.

59 Segalen, 26.

60 Segalen, 72. 
animated body dwells the whole world.-The Buddha'. ${ }^{61}$ As such, the character can be considered as a spatial principle of organization rather than a genuine psychological persona. Moreover, Siddhârtha is also at the center of a problematised and disordered economy of space. ${ }^{62}$ In the Epilogue, the disturbance of space reaches a critical dimension both in its socio-cultural and cosmic dimensions, leaving the 'Master' surrounded by emptiness. ${ }^{63}$

From the perspective of the scenic representation of space, it is even more noteworthy that, if we compare the stage directions and the characters' discourse, the play gives conflicting images of the city. In Act I, Siddhârtha first lays his eyes on the moats, sewers and slums surrounding the city, ${ }^{64}$ creating a strong contrast to the ideal image of the city inside the walls given in the stage directions of the Prologue. ${ }^{65}$ It is only later in the play that he turns his back and contemplates the 'pleasant aspects' of the 'face' of the city. ${ }^{66}$ The next stage direction gives a description of the city from the outside, from bottom to top, as if the audience could follow Siddhârtha's eyes 'climbing up aerial steps'. The palace is described as an intermediary place between earth and 'divine spheres where devas float'. This vertical structure of the world is composed of seven floors dominated by the 'formidable snowy summits of the Himalayas' ${ }^{67}$ As it is, the drama will depict a progressive deconstruction of this fairy representation of a closed and finite world. The process culminates in the final Act, where this 'vision' will reappear as a second epiphany, while Siddhârtha 'caresses space'. ${ }^{68}$ First, the city of Kapilavastou 'arises': ${ }^{69}$

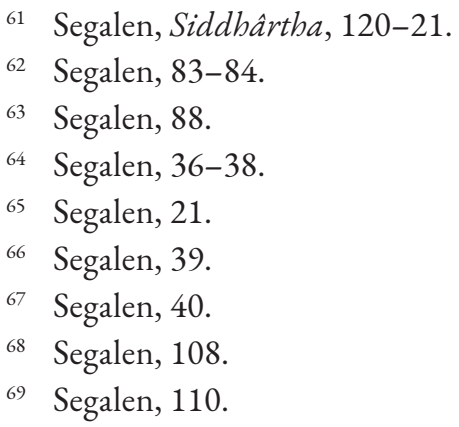


In an enlightened space, incredibly lofty mountain tops arise higher and higher as the sight of the beholder itself rises. These are the formidable Himalayas; or these are the Primordial mountains that create the shape of the world and are the Zone of the four continents. $^{70}$

Segalen refers here more clearly to Indian and Buddhist conceptions of the cosmos composed of four worlds (dvipas): the sun-shaped Aparagodana in the West, the rectangle-shape Uttarakuru in the North, the moon-shape Pürvavideba in the East, and the triangle-shape Jambudvina-our world-in the South. All these worlds are circled by the Great Iron Mountain and are surrounded by oceans; in the middle, mountain chains lie, topped by axis mundi Mount Meru. Conventionally, as in Segalen's stage directions, the Himalayas, Tibet and Mount Kailash are seen as symbolic places representing the centre of the cosmos.

\section{Achieving Realization: Buddhahood as a self-experienced spatial reordering}

What is striking in Segalen's treatment of the stage is the horizontal/vertical organization of space, indicating a phenomenological conception of theatre in which the stage corresponds both to real and imaginary places, foreshadowing a central concern of Segalen's poetics. ${ }^{71}$ This treatment of space relies on the very structure of horizon that organizes experience according to the polarities of here/there, close by/faraway, visible/invisible, known/unknown. ${ }^{72}$ But at this stage (the 'Epilogue') this cosmological and metaphysical vision is presented as a pure projection of the mind and will be recognized as such by Siddhârtha, since it provides only a 'vision', meaning the illusion of a stable reality: 'Here comes, I hope, sta-

\footnotetext{
70 Segalen, Siddhârtha, 111.

71 Métroz, 'Espaces'.

72 Collot, Un horizon.
} 
bility! It must be endless... boundless and tremendously eternal? ${ }^{73}$ As Siddhârtha himself will then underline, this poetic and mystic appeal to Infinity is only a bordered and limited conception of the world: ${ }^{74}$ 'But I have acknowledged the illusion of the phenomenal worlds! I am released from the world... and an overwhelming and peaceful ocean flows in me... it has no ripple and no edge'.75

The ensuing consequence of this realization is the dissolving of the illusionary perception of the world. Only the 'paths' trodden by Siddhârtha remain a valid (though tentative) means of cognition that allow him to be eventually called a 'Buddha' by all sentient beings: 'Do you want to walk in the middle, like the primordial king among them?'; ${ }^{76}$ 'You are the one who found [or invented] the peaceful path, you Master of the ultimate knowledge! The Enlightened! The Buddha!'77

This deconstruction and tentative rearrangement of knowledge about the world is the ultimate goal of Siddhârtha's quest contained in his own Sanskrit name, meaning 'the man whose goal has been reached'. ${ }^{78}$ But the name itself-given in translation by other characters-is subject to successive redefinitions throughout the quest, indicating an unstable identity, since all the answers that are suggested are systematically dismissed. In this, Segalen applies the Buddhist principle he particularly admired and which he calls in his Journal des îles the 'formula of self-refuge' ${ }^{79}$ It refers, according to Segalen, to the Buddha asking his disciples not to admit his teachings without having experienced them first. ${ }^{80}$

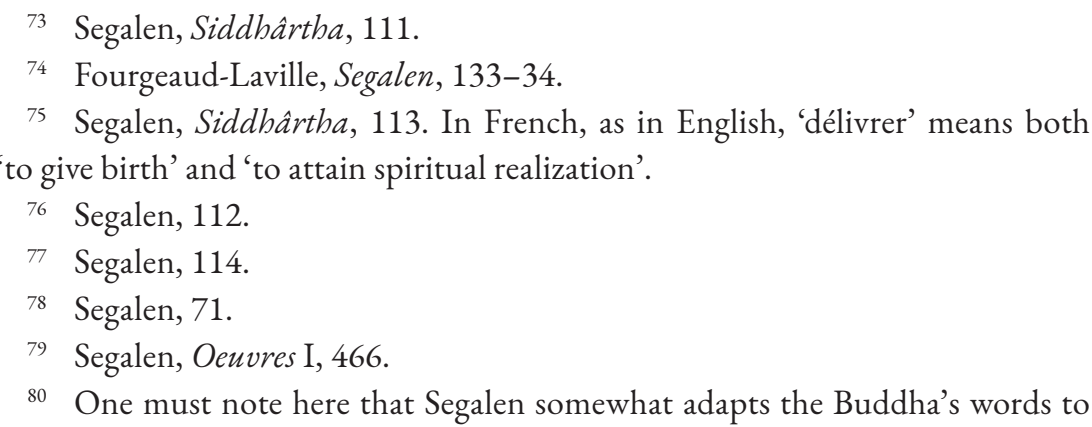
his own modernist aesthetics, since the Buddha, the Dharma, the Sangha remain the three 'refuges' for any Buddhist. 
Instead of moving toward a resolution, as stated above, the crisis is sustained and continues without culmination until the end of the final Act. In a crucial scene, hallucinated voices summon Siddhârtha to 'look at himself ${ }^{81}$ Siddhârtha, 'abashed', asks: 'Where from?' Trying to look at himself in a puddle of mud lighted by the moon, he cannot recognize himself but only his 'dreadful familiar shapes' ${ }^{82}$ The question uttered by Siddhârtha reveals a critical situation. It questions the legitimacy of the subject's position both in the world, as seen from a global perspective, and on stage, as seen from afar by the audience. Siddhârtha's question contains the global dilemma of the drama: Where does the location that legitimates my point of view on myself, the other, the world (and reciprocally our and the other's point of view) lie? In other words, where is the location that legitimates the discourse I can produce on the geographical and cultural spaces lying outside my former ecumene and which I have called ereme so far? The Buddhist connotations of this problematic appear very clearly at the core of the modern drama (in all possible senses) set by Segalen in Siddhârtha.

In fact, the author gives no conclusion to his open drama. On the contrary, the two final stage directions indicate that everything 'has become more invisible than the peaceful air': 'instead, one can see a dense cloud of an uncertain hue, which ripples a little and spreads in a huge sea' ${ }^{83}$ After walking on this vast sea:

Siddhârtha, completely penetrated by light, and stepping away from the stage to the edge of the vanishing worlds, appears far away in a rosy-lighted space where none of the Visions that have collapsed are perceptible any more. Neither shapes nor movements, but peacefulness and brightness beyond compare. Then a universal choir begins to sing. ${ }^{84}$

\footnotetext{
81 Segalen, Siddhârtha, 101.

82 'Forms' or 'shapes', the French word containing both a concrete and an abstract meaning.

83 Segalen, Siddhârtha, 113.

${ }^{84}$ Segalen, 113-14.
} 
Segalen opts for a theatrical mode that can be identified as féerie and, by doing so, diverges from or even contradicts the general scheme of the play centered on the trajectory 'not of the Buddha but of a man'. ${ }^{85}$ Interestingly, Segalen suggests here the use of visual effects that can be achieved only with the use of electric lighting. The theatrical space would hence be wholly overflown with light. As a consequence, the limits of the dramatic space (stage/off-stage) as well as the boundaries of the concrete venue (stage/audience) would be rubbed out. This, of course, is a practical way at the time to tangibly suggest the non-essentiality of the conventional world. The realization of the absence of essence is the ultimate result, rather than the main goal and final outcome, of Siddhârtha's quest. From my perspective, the ultimate step in the spatial crisis set in the play finds a means to literally convey the idea of deterritorialising the stage as a culturally-bound image of the world.

\section{Conclusion: Segalen's exoticism and the intercultural dawn of the global theatre}

Segalen's virtual staging of the Buddha's life is the tangible product of an entangled global history during a colonial and imperial crisis, a crisis that can be read in the representations of space and in particular in the complex relationship between Europe and Asia. Even though Segalen's attitude toward the East and his ideological positions were far from being 'progressive' and 'post-colonial' (if one allows me this anachronistic shortcut), the way he uses space in Siddhârtha contributes to understand one specific aspect (among the other I have pointed out in my introduction) of the 'birth of the modern world' ${ }^{86}$ From the perspective of the present study, it highlights the multi-faceted function of art and theatre, in particular, in the process of globalization. Indeed, Segalen's redefinition of exoticism shows the fear

\footnotetext{
85 This is what he wrote on the front cover of the manuscript he sent to Claude Debussy (BNF).

86 Bayly, The Birth.
} 
that world cultures might become homogenized. At the same time, it provides the means of overcoming this supposedly irretrievable loss of meaning with the fundamental role Segalen, as a modernist writer, attributed to art.

The discovery of Buddhism has thus deeply affected the dramatic space of Siddhârtha. Without implying that Segalen became a Buddhist or that his work merely attempted to represent the Buddhist material, the play proves to be thoroughly and essentially intercultural. ${ }^{87}$ The questions of interculturality in Segalen's aesthetics of Diversity and the borderline between assimilation (imperialism) and accommodation (merging into the Other) as embodied in a work of art, still need to be raised. In this respect, one may ask whether Segalen, at the time when theatre went global, as I stated in my introduction, was inspired by the actual Asian theatrical shows he had attended. Segalen recounts indeed three such experiences during his travel in 1902-1904, just before his extended stop-over in Ceylon: a Chinese theatrical show in San Francisco (December 10,1902) during a stay there on his way to Tahiti, ${ }^{88}$ a 'delusion of Javanese theatre' by the King Coronation Theatrical Company in Batavia (Jakarta) on October 25, 1904, ${ }^{89}$ and a modernized performance of nadagam in Ceylon on November 26, $1904 .{ }^{90}$ It clearly appears from these short 'world-theatre critical notes' that Segalen is suspicious of the influence of the West on Asian cultures, insofar as it damages the Other and the sensation of Diversity.

These instances of Asian performances that the author experienced entitle us to think that Segalen did not in the least intend to mimic Asian dramas (as European adaptations of Sakuntala or The Clay Chariot did) ${ }^{91}$ or even adopt Asian theatrical forms (as does Paul Claudel, to name but one famous contemporary

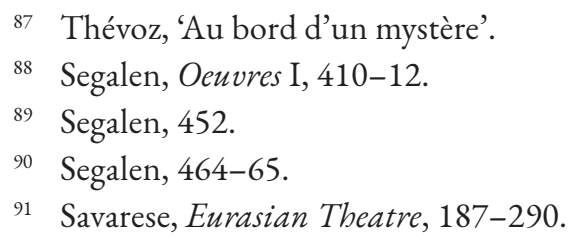


playwright, in La Femme et son ombre or in Le Soulier de Satin). ${ }^{92}$ Segalen's relationship to Asian art forms and Buddhist teachings is of a different order. In fact, Siddhârtha is the first example in his literary works where Segalen welcomes Asian cultural features and acknowledges the need for the East felt by Western artists against Western propensity to spread over the planet. This feature is found also in some of his later works. For instance, he gives to one of his most famous series of poems, Stèles, an ideogrammatical structure and aspect, and in his last unfinished poem 'Thibet' he adopts a Tibetan prosody. ${ }^{93}$ As far as the various rewritings of Siddhârtha are concerned, Segalen plans in a note dated from July 15, 1911 in Tientsin (Tianjin) to rewrite Siddhârtha's lines 'according to the rhythm of Sanskrit sūtras'. In his correspondence with Debussy about the play, April 17, 1907, he already suggested to use 'Hindu musics' in order to convey access to 'Foreign Think-

92 To get a clear insight of Claudel and Segalen's different approaches to drama and interculturality, one needs to turn to Segalen's third and last play, Le Combat pour le sol [Fighting for territory]. This drama in nine scenes, written in 1913 and revised in 1918, can be read as a sequel to Siddhârtha insofar as intercultural problems are concerned in Segalen's theatre. It was actually intended as a polemical response to Claudel's Repos du septième jour [The Seventh Day's Rest] (1896). Like in Siddhârtha, the stage is set with minute directions. It is staged in the Emperor's Palace in Ancient China and depicts the encounter between the Chinese Emperor and the ghosts of a Christian martyr and of the Foreign Concubine the Emperor had formerly executed. For Segalen, it is 'one of the most important conflicts one could imagine under the Sky since here the Sky of China meets the Latin Sky [i.e. Catholic Heaven]'. If the canvas clearly recalls that of Siddhartha, the play more distinctly plays off the problem of intercultural encounter and puts the historically known conflicts into perspective. Contrary to Claudel's play, the drama does not lead to proclaim the supremacy of one system of believes and thought (i.e. Christianity and Western civilization) over the other. As Segalen puts it: 'The unknowable course of the Influx, i.e. the inexplicable phenomenon responsible for the withering of the Earth at the core of the plot, is wider than the small religions' (Segalen, Oeuvres II, 644).

93 Thévoz, 'Victor Segalen'; Thévoz, 'Au bord d'un mystère'. 
ing' and to provide an 'introduction to sensibilities different from ours' ${ }^{94}$ All of these examples show, as the last quotation makes clear, that, while showing an enduring interest in all aspects of Asian cultures and art forms, Segalen strongly rejected throughout his literary career the idea of assimilating other cultural patterns into his own work.

Certainly, Siddhârtha is, in 1904, only Segalen's first step into Asian culture. In this respect, one later project of rewriting the play in 1911 under the name 'The Enlightened' (L'Illuminé) ${ }^{95}$ was planned as a 'satyrical [sic] drama'. Here, Segalen adds a Chinese character, the old Taoist Wise Lao-Chou, who comments with irony on the performance of the play. Segalen had supposedly turned away from Buddhism at the time. ${ }^{96}$ Yet Lao-Chou's attitude and discourse toward the conjuring tricks of Siddhârtha's staging testify to a blend of Taoism and Buddhism. Providing a distancing effect, LaoChou's character helps put into perspective not only Siddhârtha's character but the play itself. Moreover, Segalen will come back to his initial dramatic project time and again until 1917. As it appears, Siddhartha is thus an integral part of Segalen's life-long reflection on an aesthetics of Diversity as a 'doctrine spectaculaire' 997 and a radically modern poetics where the world is ultimately envisioned as an 'illusion'. As Segalen himself repeatedly admits in his letters, this idea stems from his encounter with Buddhism in Ceylon. ${ }^{8}$ Hence, Buddhism provided him with the timely and lasting means to suitably address both artistic and ideological issues of a changing world. Indeed, Siddhârtha in its various versions is a telling example that testifies to how the encounter with Buddhism proved to be crucial for modernist artists and writers such as Victor Segalen. ${ }^{99}$ It clearly

\footnotetext{
94 Segalen, Correspondance I, 696.

95 The manuscript is available at the French National Library (BNF).

96 Détrie, 'Victor Segalen'.

97 Segalen, Correspondance II, 564.

98 See especially Segalen's letter to Paul Claudel dated March 15, 1915 (Sega-

len, Correspondance II, 563-65).

99 Thévoz, 'The Yogi'.
} 
helped them gain unforeseen insights into the aesthetic issues of modernity. It simultaneously led them to problematise the interaction between cultures at the time of the unsettlement of Western culture and contributed to the process of 'decolonizing the stage' ${ }^{\text {'100 }}$ of twentieth-century global history.

\section{Acknowledgements}

I am indebted to Adelaide Russo and Pascale Hugon for their acute readings and insightful comments. The research for this publication was made possible by a grant from the Swiss National Science Foundation (PA00P1_145398) and was assisted by a research fellowship from The Robert H. N. Ho Family Foundation Program in Buddhist Studies administered by the American Council of Learned Societies.

\section{Bibliography}

\section{Primary Sources}

Arnold, Edwin. The Light of Asia, or The Great Renunciation (Mahäbhinishkramana): Being the Life and Teaching of Gautama, Prince of India and Founder of Buddhism (As Told in Verse by an Indian Buddhist). London: Trübner, 1879.

Beaunier, André. Le roi Tobal: roman [The Tobol-King: a novel]. Paris: Fasquelle, 1905.

Bouchor, Maurice. Mystères païens [Pagan Mysteries]. Paris: Flammarion, 1911.

Claudel, Paul. Théatre [Theatre]. 2 vols. Paris: Gallimard/La Pléiade, 2011.

Joly-Segalen, Annie, and Schaeffner, André, eds. Segalen et Debussy:

Textes recueillis et présentés par Annie Joly-Segalen et André

${ }^{100}$ Balme, Decolonizing. 
Schaeffner [Segalen and Debussy: Texts collected and presented by Annie Joly-Segalen and André Schaeffner]. Monaco: Le Rocher, 1962.

Laforgue, Jules. Les complaintes [Complaints] [1885]. Paris:

Flammrion, 1998.

Lahor, Jean. La Gloire du Néant [The Glory of Nothingness]. Paris:

A. Lemerre, 1896.

Maeterlinck, Maurice. Trois petits drames pour marionnettes:

Intérieur, Alladine et Palomides, La Mort de Tintagiles [Three

little dramas for marionettes: Interior, Alladine and Palomides, The Death of Tintagiles]. Edited by Fabrice van de Kerckhove. Bruxelles: Espace Nord, 2015.

- - . Petite Trilogie de la mort [Little trilogy of death]. Edited by Christian Libens. Bruxelles: Espace Nord, 2012.

Samain, Albert. La Tentation de Bouddha [The Temptation of the Buddha]. Unpublished sketches (BNF), circa 1891.

Segalen, Victor. Siddhârtha: drame en cinq actes [Siddhartha: drama in five acts]. Edited by G. Germain. Limoges: Rougerie, 1974.

- - . Oeuvres complètes [Complete works]. Edited by Henry

Bouillier. 2 vols. Paris: Robert Laffont, 1995.

- - - Correspondance [Correspondence]. Edited by Henry Bouillier, Annie Joly-Segalen, Dominique Lelong, and Philippe Postel. 3 vols. Paris: Fayard, 2004.

\section{Secondary Studies}

Almond, Philip C. The British Discovery of Buddhism. Cambridge: Cambridge University Press, 1988.

App, Urs. The Birth of Orientalism. Philadelphia: University of Pennsylvania Press, 2010.

- - - Schopenhauers Kompass [Schopenhauer's Compass].

Rorschach/Kyoto: UniversityMedia, 2011.

- - - The Cult of Emptiness: The Western Discovery of Buddhist Thought and the Invention of Oriental Philosophy. Rorschach/ Kyoto: UniversityMedia, 2012.

Artaud, Antonin. Le Théâtre et son double [The theatre and its double] [1938]. Paris: Gallimard, 1964. 
Balme, Christopher. Decolonizing the Stage: Theatrical Syncretism and Post-Colonial Drama. Oxford: Oxford University Press, 1999.

- - - 'Conceptualizing Global Theatre History'. Public lecture presented at Harvard University, Mellon School of Theater and Performance, 2013. https://vimeo.com/69573267.

Baudrillard, Jean. La Transparence du mal: essai sur les phénomènes de l'extrême [The Transparency of evil: Essay on the phenomena of the extreme]. Paris: Galilée, 1990.

Bayly, Christopher. The Birth of the Modern World 1780-1914: Global Connections and Comparisons. Malden: Blackwell, 2003.

Beal, Samuel. The Romantic Legend of Śäkya Buddha: a Translation of the Chinese Version of the Abhiniskramanasuttra. London: Truebner, 1875.

Berque, Augustin. Écoumène: introduction à l'étude des milieux bumains [Ecumene: Introduction to the study of human environments]. Paris: Belin, 2000.

Bharucha, Rustom. Theatre and the World: Essays on Performance and Politics of Culture. London: Routledge, 1993.

Bocking, Brian, Phibul Choompolpaisal, Laurence Cox, and Anne Marie Turner, eds. A Buddhist Crossroads: Pioneer Western Buddhists and Asian Networks 1860-1960. London: Routledge, 2016.

Burnouf, Eugène. Introduction à l'bistoire du buddhisme indien [Introduction to the history of Indian Buddhism]. Paris: Imprimerie royale, 1844 .

Cata, Isabelle. Le Siddhartha de Victor Segalen: une dés-orientation [Victor Segalen's Siddhartha: one of dis-orientation]. Paris: Harmattan, 2008.

Clifford, James. The Predicament of Culture: Twentieth-Century Ethnography, Literature and Art. Cambridge: Harvard University Press, 1988.

Collot, Michel. Un horizon fabuleux [A fabulous horizon]. 2 vols. Paris: José Corti, 1988.

Cordonier, Noël. Victor Segalen: l'expérience de l'euvre [Victor Segalen: the experience of the work]. Paris: Honoré Champion, 1996. 
Détrie, Muriel. 'Siddhartha de Victor Segalen, un drame autobiographique?' [Victor Segalen's Siddhartha, a autobiographical drama?]. Bulletin de l'Association Victor Segalen [Bulletin of the Victor Segalen Association] 2 (1988): 14-19.

- - - 'Le Bouddha dans les littératures occidentales' [The Buddha in Western literature]. In Dictionnaire des mythes littéraires, nouvelle édition augmentée [Dictionary of literary myth, new augmented edition], edited by Pierre Brunel, 241-53. Monaco: Le Rocher, 1994.

- - _. 'La Question de l'amour dans quelques adaptations occidentales de la vie du Bouddha' [The Question of love in some Western adaptations of the life of the Buddha]. In The Force of Vision 2, edited by Gerald Gillepsie, 391-400. Tokyo: University of Tokyo Press, 1994.

_-_. 'Victor Segalen et l'art bouddhique' [Victor Segalen and Buddhist art]. Cahier Victor Segalen [Reports on Victor Segalen]5 (1999): 11-27.

Droit, Roger-Pol. Le Culte du Néant: les philosophes et le Bouddha [The Cult of Nothingness: the philosophies and the Buddha]. Paris: Le Seuil, 1997.

Folco, Alice. 'Dramaturgie de Mallarmé' [Dramaturgy of Mallarmé]. Ph.D. dissertation, University of Paris-3 La Sorbonne-Nouvelle, 2 vols., 2006.

Forsdick, Charles. Victor Segalen and the Aesthetics of Diversity: A Journey Between Cultures. Oxford: Oxford University Press, 2010. Foucaux, Charles-Édouard. Rgya Tch'er Rol Pa, ou Développement des jeux, contenant l'bistoire du Bouddha Çakya-Mouni [Rgya Tch'er Rol Pa, or Development of games, containing the story of Śākyamuni Buddha]. 2 vols. Paris: Imprimerie royale, 1847. Fourgeaud-Laville, Catherine. Segalen ou l'expérience des limites [Segalen or the experience of limits]. Paris: Harmattan, 2002. Franklin, J. Jeffrey. The Lotus and the Lion: Buddhism and the British Empire. Cornell: Cornell University Press, 2008.

Freud, Sigmund. The Uncanny [1919]. Translated by David MacLintock. London: Penguin, 2003.

- - Civilization and its Discontents. Translated by Joan Riviere. London: L. \& V. Woolf; Institute of Psycho-Analysis, 1930. 
Fujii, Shintaro, and Christophe Triau, eds. Scènes françaises, scènes japonaises: allers-retours [French scenes, Japanese scenes: round trips]. Théâtre/Public 198. Gennevilliers: Théâtre de Gennevilliers, 2010.

Geyer, Micheal, and Charles Bright. 'World History in a Global Age'. American Historical Review 100, no. 4 (1995): 1034-60.

Glissant, Édouard. Introduction à une poétique du Divers [Introduction to a poetic of Diversity]. Paris: Gallimard, 1996. Kaempfer, Jean, Philippe Kaenel, Alain Boillat, and Pierre Gisel, eds. Points de vue sur Jésus au XXe siècle [Points of view on Jesus in the twentieth century]. Études de lettres [Study of Arts] 280. Lausanne: Université de Lausanne, 2008.

Knebusch, Julien. Poésie planétaire: l'ouverture au (x) monde(s) dans la poésie française au début du XXe siècle [Planetary poetry: The opening of worlds in French poetry at the start of the twentieth century]. Paris: Presse de la Sorbonne Nouvelle, 2012.

Laplace-Claverie, Hélène. 'Décadence et renaissance de la féerie théâtrale française autour de 1900' [Decadence and rebirth in the spectacle of French theatre around 1900]. Lendemains [The next day] 38, no. 152 (2003): 11-18.

Lévi, Sylvain. 'Les parts respectives des nations occidentales dans les progrès de l'indianisme [1924]' [Respective parts of Western nations in the progress of Indianism (1924)]. In Mémorial Sylvain Lévi [Sylvain Lévi Memorial]: 116-17. Paris: Hartmann, 1937.

Lopez, Donald. A Modern Buddhist Bible: Essential Readings from East and West. Boston: Beacon, 2002.

Losco-Lena, Mireille. La Scène symboliste (1890-1896): Pour un théâtre spectral [The symboliste Scene (1890-1896): For a spectral theatre]. Grenoble: ELLUG, 2010.

Lucet, Sophie. 'Le "Théâtre en liberté" des symbolistes: dérives de l'écriture dramatique à la fin du XIXe siècle' [The symbolists' "theatre in freedom": derivatives of dramatic writing at the end of the nineteenth centry]. Ph.D. dissertation, University of Paris-4 La Sorbonne, 1996.

MacMahan, David. The Making of Buddhist Modernism. Oxford: Oxford University Press, 2009. 
Manjapra, Kris. Age of Entanglement: German and Indian Intellectuals Across Empire. Cambridge: Harvard University Press, 2014.

Métroz, Aurélien. 'Espaces phénoménologiques d'Équipee de Victor Segalen' [Phenomenological space of Victor Segalen's Equipped]. A contrario 14 (2010): 61-77.

Mnouchkine, Ariane. 'Theatre is Oriental'. In The Intercultural Performance Reader, edited by Patrice Pavis, 93-98. London: Routledge, 1996.

Oldenberg, Hermann. Bouddha: sa vie, sa doctrine, sa communauté [Buddha: his life, his doctrine, his community]. Translated by Alfred Foucher. Paris: Alcan, 1894.

Pavis, Patrice, ed. The Intercultural Performance Reader. London: Routledge, 1996.

Reichler, Claude. 'Frontières du monde et territorialité du sujet' [Boundaries of the world and territoriality of the subject]. In L'Humanisme en géographie [Humanism in geography], edited by André Bailly et Renato Scariati, 123-34. Paris: Anthropos, 1990.

Renan, Ernest. Vie de Jésus [Life of Jesus]. Paris: Michel Lévy, 1863. Rhys Davids, Thomas. Buddhism, being a Sketch of the Life and Teachings of Gautama: the Buddha. London: Society for Promoting Christian Knowledge, 1878.

Said, Edward. Orientalism. New York: Pantheon, 1978.

Savarese, Nicola. Eurasian Theatre: Drama and Performance Between East and West from Classical Antiquity to the Present. Translated by Richard Fowler. Holstebro/Malta/Wroclaw: Icarus Publishing, 2010.

Thévoz, Samuel. 'Victor Segalen et les explorateurs du Tibet: le "pays au-delà" et la crise du paysage' [Victor Segalen and the explorers of Tibet: the 'country beyond' and the crisis of landscape]. Revue d'bistoire littéraire de la France [Review of the literary history of France] 111, no. 4 (2011): 923-52.

- _ _. "Mystères” bouddhiques. La théâtralisation des rituels tibétains par les voyageurs du début du XXe siècle' [Buddhist 'Mysteries': The theatrification of Tibetan rituals for travelers at the start of the twentieth century]. Études mongoles et sibériennes, 
centrasiatiques et tibétaines [Mongolian and Siberian, Central Asian and Tibetan Studies] 46 (2015). http://emscat.revues. org/2622.

- _ - 'On the Threshold of the "Land of Marvels": Alexandra David-Neel in Sikkim and the Making of Global Buddhism'. Transcultural Studies 1 (2016): 149-86.

- _ - 'The Yogi, the Prince, and the Courtesan: Izéyl in Europe and America'. In The Assimilation of Yogic Religions through Pop Culture, edited by Paul G. Hackett, 7-34. Lanham: Lexington Books/Rowman \& Littlefield Press, 2017.

___. "'Au bord d'un mystère:” de Ceylan au Tibet, DavidNeel, Segalen et le bouddhisme' ['On the edge of a mystery': of Ceylan in Tibet, David-Neel, Segalen and Buddhism]. In Voyages extrêmes [Extreme voyages], edited by Gilles Louÿs, Paris: Classiques Garnier, 2019 (forthcoming).

Todorov, Tzvetan. Nous et les autres: La réflexion française sur la diversité bumaine [Us and the others: The French reflection on human diversity] [1989]. Paris: Le Seuil, 1992.

Winspur, Stephen. La Poésie du lieu: Segalen, Thoreau, Guillevic, Ponge [The Poetry of place: Segalen, Thoreau, Guillevie, Ponge]. Amsterdam: Rodopi, 2006.

Zafran, Eric, ed. Gauguin's Nirvana: Painters at Le Pouldu 1889-90. New Haven/London: Yale University Press, 2001.

Ziter, Edward. The Orient on the Victorian Stage. Cambridge: Cambridge University Press, 2003. 